\title{
Nuclear Factor Kappa B Increases CX3CR1 Expression in BV-2 Microglial Cells and Aggravates Neuropathic Pain
}

\section{Zhi Ye}

Xiangya Hospital Central South University

\section{Qulian Guo}

Xiangya Hospital Central South University

\section{Xilei Li}

Xiangya Hospital Central South University

\section{E Wang}

Xiangya Hospital Central South University

Wangyuan Zou

Xiangya Hospital Central South University

\section{Zhihua Sun}

Xiangya Hospital Central South University

\section{Zhenghua He}

Xiangya Hospital Central South University

\section{Tao Zhong}

Xiangya Hospital Central South University

\section{Yingqi Weng}

Xiangya Hospital Central South University

Yundan Pan ( $\nabla$ yundanpan@163.com )

Xiangya Hospital Central South University https://orcid.org/0000-0001-5785-8786

\section{Research article}

Keywords: Neuropathic pain, NF-kB, Tumor necrosis factor-a, Microglia, BV-2

Posted Date: August 31st, 2019

DOI: https://doi.org/10.21203/rs.2.13783/v1

License: (1) (1) This work is licensed under a Creative Commons Attribution 4.0 International License.

Read Full License 


\section{Abstract}

Background: Nuclear factor kappa B is well-known for its pro-neuroinflammation function. However, it remains unknown how it increases the expression of inflammatory factors, which in turn promotes neuropathic pain. Here we investigated its role in the development of neuropathic pain in rats using a sciatic chronic constriction injury model and examined its effect in up-regulating CX3CR1 expression in BV-2 microglial cells induced by tumor necrosis factor-alpha. Methods : The sciatic nerve chronic constriction injury $(\mathrm{CCl})$ model was used to induce neuropathic pain in rats. Mechanical stimuli and radiant heat were used to evaluate mechanical allodynia and thermal hyperalgesia. The pain related behavioral effect of Nuclear factor kappa B was accessed after intrathecal administration of pyrrolidine dithiocarbamate, a nuclear factor kappa B inhibitor. BV-2 microglia activation was induced by tumor necrosis factor-alpha incubation, and the levels of inflammatory factors and CX3CR1 were assessed. Results: Intrathecal infusion of pyrrolidine dithiocarbamate, a nuclear factor kappa B inhibitor, at 100 or $1000 \mathrm{pmol} / \mathrm{d}$ prevented the development of mechanical and thermal hyperalgesia and inhibited spinal microglial activation and tumor necrosis factor-alpha expression. In addition, phospho-p65 expression revealed that transient nuclear factor kappa B activation in BV-2 microglial cells was triggered by tumor necrosis factor-alpha. and increased CX3CR1 mRNA and protein expression. Pyrrolidine dithiocarbamate inhibited the tumor necrosis factor-alpha-inducedexpression of CX3CR1. Conclusion: These results suggested that the activation of nuclear factor kappa B pathway might enhance spinal microglial activation and tumor necrosis factor-alpha expression in neuropathic pain and the phosphorylation of p65 might be responsible for tumor necrosis factor-alpha-induced CX3CR1 expression in BV-2 microglial cells.

\section{Background}

Neuropathic pain is a common symptom of the peripheral nerve injury with characteristic allodynia, hyperalgesia, and spontaneous pain. Treatment options of neuropathic pain remain limited. Previous studies suggested that the nuclear factor-KB (NF-KB) pathway plays an important role in increasing the expression of a large number of genes that are critical for immune and inflammatory responses in the central nervous system (CNS) that are responsible for the neuropathic pain [1-4]. Pyrrolidine dithiocarbamate (PDTC) is a potent NF-kB inhibitor by inhibiting factor l-kB ubiquitination and the subsequent degradation. PDTC can prevent the exposure of the nuclear localization signals on NF-KB subunits and the following gene regulation. It has been reported that intrathecal PDTC can inhibit spinal inflammatory activation and reduce pain following nerve injuries [5-7]. However, the molecular and signaling regulation mechanisms of NF-KB pathway for the neuropathic pain remain unclear. This study investigated the downstream mechanism of NF-KB in neuropathic pain in both rat model and in vitro cell line.

The contribution of inflammation to the development of neuropathic pain recently attracted substantial attention. In particular, TNF-is a major pro-inflammatory cytokine involved in neuropathic pain. An elevated level of TNF- in the CNS was detected in animals with neuropathic pain [8-12]. There is 
increasing evidence that spinal cord microglia, the main immune cell in spinal cord, plays a key role in the genesis of persistent pain. Several pain models suggested that persistent neuropathic pains including chronic constriction injury (CCl), spinal nerve ligation (SNL), and spinal cord injury as well as chronic morphine-induced hyperalgesia and tolerance are associated with the development of microgliosis in the dorsal horn of spinal cord [13-20]. It has been accepted that microglia can release proinflammatory mediators and propagate the immune response, leading to the neuropathic pain. Studies have proven that chronic intrathecal infusion of microglia inhibitor minocycline could prevent the development of SNLinduced pain in rats $[15,16,21]$ and could reduce the proinflammatory cytokine expression in rat models [22-23]. However, the molecular mechanism underlying microglial activation and neuroinflammation after nerve injury have not been well understood.

Fractalkine (also known as chemokine C-X3-C motif ligand 1) and its receptor CX3CR1 play a crucial role in the control of the biological activity of microglia. Chemokine receptor CX3CR1, which exists in spinal microglia, has been shown to mediate pain generation [25-31]. After peripheral inflammation or nerve injury, CX3CR1 expression increased in microglia at pain-relevant area in sciatic inflammatory neuropathy, $\mathrm{CCl}$, SNL, monoarthritic, and vincristine-induced neuritis murine models. Blocking CX3CR1 attenuated and delayed neuropathic pain [25-30]. It is not yet clear whether the TNF- and NF-KB pathway can induce CX3CR1 expression in microglia. A likely signal transduction pathway for TNF- involves the phosphorylation of the inhibitor factor I-KB andthe subsequent translocation of NF-KB subunit p65 to the nucleus.

Therefore, in this study, we firstly tested the hypothesis that intrathecal PDTC inhibits neuropathic pain by inhibiting microglial activation and TNF- expression in rats. We then measured CX3CR1 expression in BV-2 microglial cells under TNF- stimulation and investigated the role of NF-KB p65 in the regulation of CX3CR1 expression in these cells.

\section{Methods}

\section{Animals}

Male Sprague-Dawley rats weighing 250-350g at the time of surgery were housed individually in bedded cages on a natural 12-hr light/12-hr dark cycle $(7 \mathrm{am} / 7 \mathrm{pm})$ in a temperature $(21 \pm 1 \mathrm{C})$ and humiditycontrolled specific pathogen free room with food and water provided ad libitum. All rats were acquired from Laboratory Animal Center of Xiangya Hospital, Central South University. These experiments were approved by the Institutional Animal Care and Use Committee in Central South University.

\section{Surgical procedures}

Rats were anesthetized with intraperitoneal injection (IP) of 300 to $400 \mathrm{mg} / \mathrm{kg}$ chloral hydrate and maintained at $100 \mathrm{mg} / \mathrm{hr}$. For repeated intrathecal injections, chronic catheters were constructed and 
implanted by lumbar approach according to a method described previously [32]. The indwelling catheters were used to microinject drugs or vehicle into the cerebrospinal fluid space surrounding the lumbosacral spinal cord. Briefly, a sterile PE-10 tube filled with saline was inserted through the L5/L6 intervertebral space, and the tip of the tube was placed at the spinal lumbar enlargement level. The cannulated rats were allowed to recover for 5 days and were housed individually. Rats that showed any neurologic deficit resulting from the surgical procedure during the whole experiment were excluded from the experiment and euthanatized by carbon dioxide inhalation.

PDTC (molecular weight, 164.29) was purchased from Sigma-Aldrich (St Louis, Mo) and dissolved in normal saline. The doses for intrathecal PDTC were selected according to a previous study (Wei et al., 2007) and our preliminary experiments. $10 \mu \mathrm{I}$ PDTC (100 or $1000 \mathrm{pmol} / \mathrm{d})$ or saline was administered followed by a flush of $5 \mu \mathrm{l}$ saline to ensure that drugs were delivered into the sub-arachnoid space. In PDTC treated rats, PDTC was injected daily for 4 consecutive days from 1 day before to 2 days after CCI or from 3 to 6 days after $\mathrm{CCl}$ ( $n=8$ per group). Catheter placements were verified upon completion of behavioral testing by visual inspection after euthanasia under anesthesia with chloral hydrate.

\section{Chronic constriction injury}

Neuropathic pain was induced following the method reported by our previous studies [32, 33]. Rats were anesthetized and placed under a microsurgical apparatus in a prone position. An incision was made on the left thigh with the left sciatic nerve exposed. Four loosely tied ligatures (4-0 chromic catgut) were applied $1 \mathrm{~mm}$ apart around the left sciatic nerve above its trifurcation. For rats in the sham-operated groups, the left sciatic nerve was exposed but not ligated.

\section{Behavioral Assessment-Mechanical Threshold and Thermal Threshold}

The hind-paw withdrawal threshold (PWT) to an Electrovonfrey (IITC/Life Science Instruments, Woodland Hills, Calif) probe and paw withdrawal latency (PWL) to noxious radiant heat were determined before surgery (baseline, day 0 ) and once daily on each post-surgery day. All the behavioral tests were performed between 10 am and 3pm by an examiner blinded with respect to the treatment rendered.

To quantify mechanical sensitivity of the foot, the threshold of foot withdrawal in response to an increasing mechanical stimulus was determined using the Electrovonfrey apparatus. Rats were placed in a transparent plastic dome with a metal mesh floor, which allowed access to the plantar surface of the hind paw and habituated to this environment for 30 mins. The Electrovonfrey probe was pressed perpendicular to the plantar surface of the hind paw with continuous force. A positive response was noted if the hind paw was sharply withdrawn, and the force was recorded on the screen simultaneously. 
Each trial was repeated 3 times with 5-min intervals, and the mean value was used as the force to produce withdrawal responses.

The latency of foot withdrawal to a noxious heat stimulus was measured using a Hargreaves apparatus (Ugo Basile, Comerio, Italy). Rats were placed separately on a temperature-controlled, 3-mm-thick glass floor under which a light box was located, and habituated to the environment for 30 mins before testing. The movable radiant-heat source beneath the glass floor was focused on the planter surface of the hind paw. A cutoff was set at 20 secs to avoid tissue damage. Light intensity was preset to obtain a baseline latency of approximately 12 secs. Five PWLs were collected with 5-min intervals, and the average of the middle 3 latencies was used for the following analysis [34, 35].

\section{Immunohistochemistry}

After the last behavioral assessment, on days 3 and 7 after $\mathrm{CCl}$ surgery, rats were deeply anesthetized with chloral hydrate (450 mg/kg, IP) and perfused intracardially with heparinized normal saline, followed by $4 \%$ paraformaldehyde in phosphate-buffered saline (PBS). The spinal cord around L4 and L5 was removed and postfixed in the same fixative at RT for $4 \mathrm{hrs}$. All specimens were cryoprotected in $30 \%$ (wt/vol) sucrose. Spinal cords were cut transversely by cryostat into $10 \mathrm{~m}$ floating sections. Sections were washed with PBS followed by PBS containing $0.3 \%$ Triton X-100 (PBST) for 10 mins twice, and treated with $0.3 \%$ hydrogen peroxide in PBST for at least 15 mins to exhaust the endogenous hydrogen peroxidase. Nonspecific binding was blocked by $3 \%$ normal goat serum plus $2 \%$ bovine serum albumin in PBST for $1 \mathrm{hr}$. Sections were incubated at RT overnight with primary mouse monoclonal antibody (antiOX42, 1:200, Santa Cruz; anti-TNF- a, 1:200, Biolegend) in PBST plus 3\% normal goat serum. Sections were washed with PBST 3 times for 10 mins each and incubated with goat anti-mouse biotinylated secondary antibody (1:1000; Cell Signaling, Beverly, Mass) for $1 \mathrm{hr}$ at RT. After sections were washed further with PBST 3 times, avidin-biotin-horseradish peroxidase complex (Pierce, Rockford, III) in PBST was applied in 1:160 dilution to sections for $1 \mathrm{hr}$. Antigens were visualized by combining equal volumes of an ammonium nickel sulfate solution ( $30 \mathrm{mg} / \mathrm{mL}$ in $0.1 \mathrm{M}$ sodium acetate, $\mathrm{pH} 6.0$ ) and a diaminobenzidine solution ( $4 \mathrm{mg} / \mathrm{mL}$ in PBS) in the presence of $0.01 \%$ hydrogen peroxide. Floating sections were spread flat on slides, air dried, rinsed with distilled water for $1 \mathrm{~min}$, and dehydrated through an ethanol gradient (70\% once, $95 \%$ twice, and 100\% twice) for 1 min each and then in xylene for 3 mins twice. Sections were cover slipped with Permount mounting medium (Merck, Darmstadt, Germany). Images were acquired with a Leica 4000 light microscope (Leica Microsystems $\mathrm{GmbH}$, Wetzlar, Germany). Assessments of OX42-positive or TNF-a-positive cells were performed in 3 sections chosen randomly from $L 4 / 5$ spinal cord of rats. A manual method was employed to measure the total number of OX42 and TNF-a IR cells in ipsilateral spinal dorsal horn with the microscope under 250x magnification.

\section{Cell culture and treatment}


BV-2 microglial cells were obtained from German collection of microorganisms and cell culture was purchased from Deutsche Sammlung von Mikroorganismen und Zellkulturen. Both were adopted as the substitute for microglias and were plated $\left(4 \times 10^{4} \mathrm{cells} / \mathrm{cm}^{2}\right)$ in culture flasks. Cells were cultured in RPMI1640 (Gibco, Grand Island, NY, USA), supplemented with 10\% fetal calf serum, in a humidified atmosphere with $5 \% \mathrm{CO}_{2}$. The homogenous cells between the fourth and eighth passages were used.

TNF-a $(20 \mathrm{ng} / \mathrm{ml})$ and PDTC (100 mol/l) were applied to BV-2 cells. Serum-free medium was used as the negative control. Immunocytochemistry, RT-PCR and western blotting were used to assess cell NF-KB pp65 protein expression, and CX3CR1 protein and mRNA expression.

\section{Immunocytochemistry}

Cells were fixed in $4 \%$ paraformaldehyde for $20 \mathrm{~min}$ at room temperature (RT) and washed three times with phosphate-buffered saline (PBS). Then cells were incubated with $10 \%$ goat serum in PBS containing $0.2 \%$ Trion X-100 at RT for 20 min to block the unspecific binding of antibodies. After the blocking solution had been washed out, cells were incubated overnight with primary antibody (NF-kB p-p65, 1:100, Abcam, Cambridge, UK). Then cells were washed and incubated with a secondary antibody (horseradish peroxidase-polymer-goat anti-rabbit immunoglobulin G; 1:1000) for $20 \mathrm{~min}$. After cells were washed further with PBS 3 times, antigens were visualized by combining equal volumes of an ammonium nickel sulfate solution $(30 \mathrm{mg} / \mathrm{mL}$ in $0.1 \mathrm{M}$ sodium acetate, $\mathrm{pH} 6.0)$ and a diaminobenzidine solution $(4 \mathrm{mg} / \mathrm{mL}$ in PBS) in the presence of $0.01 \%$ hydrogen peroxide. For nuclear staining, the cells were washed and incubated with hematoxylin. Images were acquired with a Leica 4000 light microscope (Leica Microsystems $\mathrm{GmbH}$, Wetzlar, Germany). Assessments of NF-KB p-p65-positive cells were performed in 3 slides chosen randomly.

\section{Reverse transcription polymerase chain reaction (RT-PCR)}

Total RNA was isolated from cells using Trizol reagent (Invitrogen, Carlsbad, CA, USA) and quantified by spectrophotometry. First strand cDNA was synthesized from $1 \mu \mathrm{g}$ of total RNA via the ReverTra Ace-aTM reverse-transcription system (TOYOBO). PCR products were analyzed by electrophoresis on $1.5 \%$ agarose gel containing ethidium bromide. GAPDH gene expression was used as a standard. CX3CR1 was amplified using CX3CR1 primers and the sequences of the forward and reverse primers are: 5ACGATGTCTGGGTGACTAC-3 and 5-GTATGGTGTCCAGAAGAGGA-3, respectively. The sequences of GAPDH forward and reverse primers are: 5-ACCACAGTCCATGCCATCAC-3 and 5-

TCCACCACCCTGTTGCTGTA-3, respectively.

\section{Western blotting analysis}


The method was described previously [36]. Western blot analysis was performed to evaluate CX3CR1 expression in BV-2 cells after cells were incubated with various drugs for 2, 4 or 6 hours. Cultured cells were treated with lysis buffer and then mechanically digested to release the proteins. Lysate was centrifuged at $9000 \mathrm{rpm}$ for 10 mins and the supernatant was taken for western blotting. Equal amount of protein $(30 \mu \mathrm{g})$ was loaded on each lane, separated by $10 \%$ sodium dodecyl sulfate-polyacrylamide gel electrophoresis, and transferred onto polyvinylidene difluoride membranes. The membranes were blocked in $10 \%$ nonfat dry milk for $2 \mathrm{hr}$ at room temperature and incubated overnight at $4{ }^{\circ} \mathrm{C}$ with rabbit polyclonal anti-CX3CR1 antibody (1:500; eBioscience); or anti-GAPDH antibody (1:8000; Cell Signaling). The blots were incubated for $2 \mathrm{hr}$ at room temperature with horseradish peroxidase-conjugated mouse anti-rabbit (1:2000, Santa Cruz Biotechnology). Signals were visualized using enhanced chemiluminescence (Pierce) and exposed onto x-ray films for 1 to 10 mins. All western blotting analysis was performed at least 3 times, and parallel results were obtained. X-ray films with blotting bands for each sample from different rats were scanned, and analyzed using the digitalized scientific software program UN-SCAN-IT (Silk Scientific Corporation, Orem, Utah). Concentration of protein was determined by densitometric analysis and expressed as relative densitometric unit to that of GAPDH.

\section{Statistical Analysis}

All experiments were performed in triplicate, and data were expressed as mean $\pm S E M$. Data analysis was performed using SPSS 16.0 software. Two-way analysis of variance (ANOVA) with post hoc Tukey test was used to compare the behavioral data of different experimental groups. Image-analysis data were compared between groups with one-way ANOVA with post hoc Bonferroni test. A value of $P<0.05$ was considered statistically significant.

\section{Results}

\section{The effects of repeated intrathecal administration of PDTC on ipsilateral hind paw pain in sham and $\mathrm{CCl}$ rats}

Figure 1 shows the effects of PDTC (100 or $1000 \mathrm{pmol} / \mathrm{d}$, i.t. 4 days) on mechanical allodynia and thermal hyperalgesia of ipsilateral hind paws in sham and $\mathrm{CCl}$ rats. In the sham group, no difference was observed in the mechanical thresholds and thermal latency for different doses of PDTC. In the CCI group, the neuropathic pain exhibited remarkable mechanical allodynia and thermal hyperalgesia. Paw withdrawal threshold (PWT) to electrovonfrey filaments and paw withdrawal latency (PWL) to a radiant heat source of CCl-rats decreased over time. PDTC increased the mechanical threshold $(P<0.05$; Figure $1 B)$ and thermal latency $(P<0.05$; Figure $1 A)$ in a dose-dependent manner in $\mathrm{CCI}$ rats. Significant impact of PDTC on mechanical allodynia and thermal hyperalgesia was observed 1 day after PDTC treatment. The maximal effect on thermal latency and mechanical thresholds was achieved with $1000 \mathrm{pmol} / \mathrm{d}$ of 
intrathecal PDTC. Post-hoc analyses showed that PDTC at $1000 \mathrm{pmol} / \mathrm{d}$ induced higher thresholds 1-4 days after treatment $(P<0.05)$.. Intrathecal administration of PDTC delayed the onset of neuropathic pain $(P<0.05$, Figure 1A, left panel; $1 \mathrm{~B}$, left panel) in a dose-dependent manner and reversed the pain behaviors $(P<0.05$, Figure $1 \mathrm{~A}$, right panel; 1B, right panel $)$ in rats.

\section{The effects of repeated intrathecal administration of PDTC on spinal microgliosis in sham and $\mathrm{CCl}$ rats}

OX-42 expression in the spinal cord was measured to evaluate the influence of PDTC (100 or 1000 $\mathrm{pmol} / \mathrm{d}$, i.t.) on microglial activation after 4 days of treatment. As shown in Figures 2 and 3, 0X-42 expression increased significantly in the ipsilateral spinal cord in $\mathrm{CCl}$ rats $(P<0.05)$.. PDTC decreased the expression of $\mathrm{OX}-42$ and the number of ipsilateral spinal $\mathrm{OX}-42$ immunoreactive (IR) cells in a dosedependent manner. The number of OX-42 IR cells decreased at both doses $(P<0.05)$..

\section{The effects of repeated intrathecal administration of PDTC on spinal TNF-aprotein expression in sham and $\mathrm{CCl}$ rats}

TNF- level in spinal cord was measured by immunohistochemistry $(\mathrm{IHC})$ analysis to evaluate the influence of PDTC on proinflammatory factor generation after repeated infusion of PDTC (100 or 1000 $\mathrm{pmol} / \mathrm{d}$, i.t.) for 4 days. As shown in Figures 4 and 5, TNF- expression increased significantly in the ipsilateral spinal cord in $\mathrm{CCl}$ rats $(P<0.05)$.. PDTC decreased the expression of TNF- in a dose-dependent manner, compared to that of $\mathrm{CCl}$ group $(P<0.05)$.. The number of TNF- IR cells decreased at both doses $(P<0.05)$.

\section{PDTC inhibited TNF-a-induced p-p65 expression in microglial cells}

To determine whether TNF-a mediate microglial activation via the NF-KB p-p65 signaling pathway, microglial BV-2 cells were pretreated with PDTC $(100 \mu \mathrm{mol} / \mathrm{l})$ for $1 \mathrm{hr}$ and then incubated with TNF-a (20 $\mathrm{ng} / \mathrm{ml}$ ) for $1 \mathrm{hr}$. The expression of NF-kB p-p65 was examined by immunocytochemistry (ICC). Very low level of nuclear p-p65 expression existed in the untreated cells (Fig. 6 and 7).. After TNF-induction, nuclear p-p65 expression increased and reached the peak in $1 \mathrm{hr}$ (Fig 6).. TNF-dependent phosphorylation of NF-KB p65 was inhibited when cells were pretreated with PDTC (100umol/I) $)$ while PDTC can't alter the constitutive p-p65 expression in microglial cells (Fig 6 and 7).. 


\section{PDTC inhibited TNF-a-induced CX3CR1 expression in microglial cells}

To investigate the possible relationship between TNF- $a$ and microglial CX3CR1 expression in vitro, extracts from microglial BV-2 cells stimulated with TNF-a were examined by western blotting analysis and reverse transcription polymerase chain reaction (RT-PCR). Microglial BV-2 cells were pre-treated with PDTC $(100 \mu \mathrm{mol} / \mathrm{l})$ for $1 \mathrm{hr}$ and then incubated with TNF-a $(20 \mathrm{ng} / \mathrm{ml})$. TNF-a incubation induced an increase in CX3CR1 mRNA in a time-dependent manner. With the presence of TNF-a, CX3CR1 mRNA expression was observed as early as $30 \mathrm{~min}$ and peaked in $2 \mathrm{hrs}$ (Fig. 8).. The increase in CX3CR1 protein expression was noted after cells were treated with TNF-a for $2 \mathrm{hr}$, and CX3CR1 protein expression reached the peak at hour 4 (Fig. 9).. The control group failed to demonstrate a meaningful increase in the expression of CX3CR1, although a constitutive expression was observed. These results indicated that PDTC inhibited the expression of constitutive and TNF-a-induced CX3CR1 mRNA and protein (Fig. 8 and 9)..

\section{Discussion}

In this study, we established a classic model of nerve injury-induced neuropathic pain via chronically constricting the left sciatic nerve of male rats. Similar to what reported by Bennett et al. [37], sciatic constriction induced pain-related behavioral signs of mechanical allodynia and thermal hyperalgesia. The characteristic changes in pain threshold indicated that the model was successfully established for this study.

Here, we demonstrated an important but previously unrecognized role of NF-kB in CCl-induced neuropathic pain. Daily intrathecal infusions of NF-KB inhibitor PDTC (100 and $1000 \mathrm{pmol} / \mathrm{d})$ for 4 consecutive days delayed the onset of neuropathic pain and the activation of spinal microgliosis and inflammation in a dose-dependent manner. Moreover, repeated intrathecal administration of PDTC 3 days after $\mathrm{CCl}$ reversed the established mechanical allodynia and thermal hyperalgesia, and reduced activated spinal microglial cells and inflammatory cytokine production in rats. No obvious neurotoxicity was observed after repeated intrathecal infusion of PDTC (1000 pmol/d). The inhibition of the NF-KB signaling pathway was accompanied with decreased injury-induced pain behavior and central nerve system inflammation, suggesting the correlation between spinal NF-KB and neuropathic pain. Therefore, NF-KB is a promising therapeutic target for the prevention of nerve injury-induced neuropathy and neuroinflammation.

NF-KB is a protein complex that controls transcriptional DNA, cytokine production and cell survival and participates in cell responses to stimuli, such as stress, cytokines, free radicals, etc. NF-kappa B also plays a key role in regulating the immune response to nerve injury. Previous research indicated that the incorrect regulation of NF-KB is associated with neuroinflammation and neuropathic pain development in rat model of neuropathic pain [38]. NF-KB is believed to promote the expression of proinflammatory genes 
and lead to neuronal hypersensitivity in nervous system. In our study, TNF-a expression and microglial activation increased around the primary afferents and second-order neurons in laminae I to III in spinal cord. TNF-a in the dorsal horn may enhance the excitability of sensory neurons and activation of microglia [8-12]. The excitatory signal from the injured nerves to these spinal areas triggered TNF-a production and microglial activation. Furthermore, biochemical changes along the neuronal sensory pathway may be other causes. TNF- $a$ is a member of superfamily of type II proteins containing a fulllength membrance TNF-a (mTNF-a) that is cleaved by inducible TNF converted enzyme to release diffusible peptides (soluble TNF-a (sTNF-a)). Each peptide performs a different function. In recent studies, nerve injury-induced pain resulted in an increase in mTNF-a in dorsal horn measured by immunohistochemistry or western blot, while the sTNF-a was unable to be detected in spinal cord by ELISA [39]. This is in agreement with the observation in our study. The mTNF-a might serve to mediate bidirection cell-to-cell crosstalk in neuropathic pain resulting from physical nerve injury. However, sTNF-a is the functional form of TNF-a in neupathic pain caused by paclitaxel and may play a role in initiating inflammatory reactions [40]. Further research might be needed to illuminate the involvement of NF-KB in transcriptional promotion of TNF- $\alpha$ in neuropathic pain. Microglia were also activated in the lateral part of the spinal ventral horn and may play a possible role of phagocytosis around motor neurons [41]. In this study, we observed the dose-dependent suppressive effect of intrathecal PDTC on TNF-a expression and microglial activation induced by $\mathrm{CCl}$, therefore, our data demonstrated that NF-kB activation could mediate TNF-a production and microglial activation. These data suggested that the activation of NF-KB pathway facilitated the development of neuropathic pain via regulating CNS inflammation.

\section{Our results suggest that}

However, the activation of NF-kB regulated genes is different in the various conditions and could account for development of neuropathic pain. PDTC was also reported to reduce the levels of CX3CR1, COX-2, $\mathrm{IL}-1$ and IL- 6 in the rats of pain models $[22,32,38]$. Hence, the inhibitory effects of PDTC on these proinflammatory factors may be additional reasons for its analgesic activity observed in this study.

In the in vitro model developed by adding pro-inflammatory factor TNF-a to BV-2 microglial cultures attempted to mimic the signaling cues present in the in vivo neuropathic pain environment. Microglial cells treated with TNF-a presented an activated phagocytic phenotype with morphologic changes and intense phospho-p65 labeling. Activated BV-2 microglia showed bigger soma and few ramifications. Control BV-2 microglia, by contrast, showed smaller soma with distal arborization, characteristic of ramified unactivated microglia. Phospho-p65 is a molecule present in the cell nuclei related to the activation of NF-KB signaling pathway.

In CNS, enhanced spinal microglial CX3CR1 expression was believed to be directly related to neuropathic pain and inflammation, although the factors involved in the regulation of microglial CX3CR1 expression have not been well-characterized. We previously reported that CCI stimulates CX3CR1 expression in spinal cord [32]. In this study, we demonstrated that TNF-a induced an increase in CX3CR1 mRNA and protein 
expression in vitro in BV-2 microglial cells. Similar observations were reported on CX3CR1 expression in response to TNF-a in rat aortic smooth muscle cells [42]. The inducible CX3CR1 is responsible for the prompt activation of microglia during the inflammatory response. Spinal cord microglia play an important role in the genesis of persistent pain by releasing the proinflammatory cytokines TNF-a and IL1 , and brain derived neurotrophic factor (BDNF) $[15,20-24,43]$. Therefore, our results proved that enhanced TNF-a in CNS disorders is associated with neuropathic pain.

However, the molecular mechanism for the increased expression of CX3CR1 following TNF-a treatment remains unclear. NF-KB was reported to be involved in TNF-a-induced CX3CR1 expression in human vascular smooth muscle cells and cryptosporidium parvum infection-induced CX3CR1 expression in epithelial cells $[44,45]$. There may be NF-KB consensus sites in the promoter region of rat CX3CR1 gene that regulate $\mathrm{CX} 3 \mathrm{CR} 1$ production. Our data showed that TNF-a induced an early and rapid nuclear translocation of $\mathrm{p}-\mathrm{p} 65$. Therefore, the nuclear translocation of NF-kB p-p65 in BV-2 microglial cells may be the critical step for inflammation in microglia, and is involved in TNF-a-induced CX3CR1 expression.

The CX3CR1 is a novel but not the only target gene of NF-KB signaling pathway in central nervous system. Its target genes are still incompletely understood in the nervous system. Already known regulated genes in neuronal tissue make up inducible NO-synthase (iNOS), $\mu$-opiod receptors, brain-derived neurotrophic factor, calmodulin-dependent protein kinase II, and catechol-o-methyltransferase (COMT) $[46,47]$. Previous studies show that increased NF-kB activity enhances transcription of genes that cause pain (e.g., iNOS) and decreases ones that ease pain (e.g., COMT). Therefore, inhibition of NF-KB signaling pathway might exert a useful appraoch for the development of new analgesics.

The activation of NF-KB can be blocked by PDTC, without affecting the DNA binding activity of other transcription factors. In the present study, PDTC prevented NF-KB p65 phosphorylation and inhibited CX3CR1 mRNA and protein expression in BV-2 microglial cells, indicating that NF-KB p65 may be essential for CX3CR1 induction in response to TNF-a in BV-2 microglial cells. These findings further confirmed the results of our rat experiments of neuropathic pain, and proved that NF-kB was essential for microglia activation in neuropathic pain in CNS.

NF-KB may not be the only transcription factor involved in the TNF-a-induced up-regulation of CX3CR1 gene in BV-2 cells, because PDTC pretreatment did not completely inhibit the production of CX3CR1. The results that PDTC inhibited the constitutive expression of CX3CR1 without altering the constitutive p-p65 expression indicated that PDTC might suppress the constitutive expression of CX3CR1 through some pathway other than NF-KB, such as nuclear factor erythroid 2 related factor 2 (Nrf2). PDTC is found to activate Nrf2 signaling and have a neuroprotective and antioxidative function [48]. Recently, several other transcription factors were reported to regulate CX3CR1 gene expression in response to TNF- $a$ in various cells. For example, HIF-1, AP-1 and STAT1/3 are also essential for CX3CR1 expression in various cells. A change on the DNA methylation status of CX3CR1 gene promoter can change its activity and gene expression [49-51]. Therefore, the involvement of those transcription factors in transcriptional regulation of CX3CR1 remains to be evaluated in TNF-a-stimulated BV-2 cells. 
There are still some limitations of our study. Although blockade of NF-kB inhibited CCl-induced microglial activation and TNF-a expression by immunohistochemistry assay, we don't know how these molecules and signals are involved. Some study shows co-localization of microglia CX3CR1 and extracellular signal-regulated protein kinase 5 (ERK5) by immmunofluorescence labelling of them in the dorsal horn and suggests that CX3CR1 enhances nerve injury-induced pain hypersensitivity through the ERK5 signaling pathway [52]. Further study is needed to explore the direct target molecules for NF-KB and CX3CR1 in spinal microglia.

PDTC is a synthetic compound is largely used as an NF-KB inhibitor by inhibiting factor l-kB ubiquitination, however, it can also regulate other cell signaling, such as anti-apoptotic signaling, and we don't know the relationship between the pain-related NF-KB activation pathway and other effects of PDTC. Some specifical NF-KB inhibitors or siRNA might be the promising approaches to selectively impair NF-KB activation. However, because NF-KB also fulfils a number of physiological functions, complete inhibition may lead to serious effects. Recent studies have shown the embryonic lethality in mice with completely knockout of p65 [53], and another study indicated an inhibitory effect of p65-siRNA on transcription of NF-KB-regulated proteins such as COX-2 [54]. Therefore, drugs that selectively inhibit pain-promoting NF-KB activity while leaving physiological functions unaffected would be beneficial to clinic pain management and be explored in future research.

\section{Conclusions}

We have shown the protective effect of intrathecal PDTC on the development of nociceptive behaviors induced by $\mathrm{CCl}$ in rats. The activation of NF-KB pathway may contribute to spinal microglial activation and TNF-a up-regulation. We also demonstrated that the phosphorylation of NF-KB p65 was responsible for TNF-a-induced CX3CR1 expression in BV-2 microglial cells. These results enhanced our understanding of molecular mechanisms underlying increased CX3CR1 expression and microglia activation, and neuropathic pain associated with elevated levels of TNF-a in CNS inflammation.

\section{Abbreviations}

NF-kB: Nuclear factor kappa B;

CCl: chronic constriction injury;

PDTC: pyrrolidine dithiocarbamate;

TNF-a: tumor necrosis factor-alpha;

CNS: central nervous system;

SNL: spinal nerve ligation;

BDNF: brain derived neurotrophic factor; 
IR: immunoreactive;

PBS: phosphate-buffered saline;

i.t.: intrathecal;

PWT: Paw withdrawal threshold;

PWL: Paw withdrawal latency;

IHC: immunohistochemical;

ICC: immunocytochemistry;

RT-PCR: Reverse transcription polymerase chain reaction

\section{Declarations}

\section{Author contributions}

Zhi Ye and Yundan Pan helped with animal experiments and drafted the work. Qulian Guo, Xilei Li, E Wang and Zhihua Sun helped with cell experiments and biological techniques. Wangyuan Zou, Zhenhua $\mathrm{He}$, Tao Zhong and Yingqi Weng helped with analysis of the data.

\section{Conflicts of interest}

The authors have declared no conflicts of interest.

\section{Acknowledgments}

We thank the central lab technicians in Xiangya hospital of Central South university for technical supporting.

\section{Funding}

This work was supported by grants from National Nature Science Foundation of China (81501078, 81471135 and 81370251 ).

\section{Availability of data and materials}


All the datasets generated and analyzed during this study are kept in the Dept of Anesthesiology, Xiangya hospital of Central South university and they are available from the corresponding author on reasonable request

\section{Ethics approval and consent to participate}

All experiments followed the guidelines and were approved by the Animal Care and Use Committee of Xiangya Hospital (Changsha, People's Republic of China).

\section{Consent to publish}

It is not applicable as there is no patient information in this manuscript.

\section{Competing interests}

The authors declare that they have no competing interests.

\section{References}

1. Liu Zhi-hua, Miao Gui-shen, Wang Jun-nan, Yang Cong-xian, Fu Zhi-jian, Sun Tao. Resolvin D. Inhibits Mechanical Hypersensitivity in Sciatica by Modulating the Expression of Nuclear Factor-[kappa]B, Phospho-extracellular Signal-regulated Kinase, and Pro- and Anti-inflammatory Cytokines in the Spinal Cord and Dorsal Root Ganglion. Anesthesiology 2016;124: 934-44.

2. Orita S, Miyagi M, Kobori S, Gemba T, Ishikawa T, Inoue G, Toyone T, Aoki Y, Eguchi Y, Takahashi K, Ohtori S. IKB kinase $\beta$ inhibitor downregulates pain-related neuropeptide production in the sensory neurons innervating injured lumbar intervertebral discs in the dorsal root ganglia of rats. Spine J. 2013; 13: $284-8$.

3. Popiolek-Barczyk K, Makuch W, Rojewska E, Pilat D, Mika J. Inhibition of intracellular signaling pathways NF-kappa B and MEK1/2 attenuates neuropathic pain development and enhances morphine analgesia. Pharmacol Rep. 2014; 66: 845-51.

4. Zhou, YL, Jiang GQ, Wei JR, Zhang HH, Chen W, Zhu HY, Hu SF, Jiang XH, Xu GY. Enhanced binding capability of nuclear factor-kappa B with demethylated $\mathrm{P} 2 \mathrm{X} 3$ receptor gene contributes to cancer pain in rats. Pain 2015; 156:1892 -1905.

5. Bai L, Zhai C, Han K, Li Z, Qian J, Jing Y, Zhang W, Xu JT. Toll-like receptor 4-mediated nuclear factor$K B$ activation in spinal cord contributes to chronic morphine-induced analgesic tolerance and hyperalgesia in rats. Neurosci Bull 2014囚30冈936 - 948.

6. Qian Li-Ping, Shen Shi-Ren, Chen Jun-Jie, Ji Lu-Lu, Cao Su. Peripheral KATP activation inhibits pain sensitization induced by skin/muscle incision and retraction via the nuclear factor-kB/c-Jun N- 
terminal kinase signaling pathway. Mol Med Rep. 2016; 14:2632-8.

7. Wei XH, Zang Y, Wu CY, Xu JT, Xin WJ, Liu XG. Peri-sciatic administration of recombinant rat TNFalpha induces mechanical allodynia via upregulation of TNF-alpha in dorsal root ganglia and in spinal dorsal horn: the role of NF-kappa B pathway. Exp Neurol. 2007; 205:471-84.

8. Bohren Y, Tessier LH, Megat S, Petitjean H, Hugel S, Daniel D, Kremer M, Fournel S, Hein L, Schlichter R, Freund-Mercier MJ, Yalcin I, Barrot M. Antidepressants suppress neuropathic pain by a peripheral ß2-adrenoceptor mediated anti-TNFa mechanism. Neurobiol Dis. 2013; 60:39-50.

9. Dellarole A, Morton P, Brambilla R, Walters W, Summers S, Bernardes D, Grilli M, Bethea JR. Neuropathic pain-induced depressive-like behavior and hippocampal neurogenesis and plasticity are dependent on TNFR1 signaling. Brain Behav Immun. 2014; 41:65-81.

10. Lima CK, Silva RM, Lacerda RB, Santos BL, Silva RV, Amaral LS, Quintas LE, Fraga CA, Barreiro EJ, Guimaraes MZ, Miranda AL. LASSBio-1135: a dual TRPV1 antagonist and anti-TNF-alpha compound orally effective in models of inflammatory and neuropathic pain. PLoS One 2014; 9:e99510.

11. Xu, Ting; Li, Dai; Zhou, Xin; Ouyang, Han-Dong; Zhou, Li-Jun; Zhou, Hang; Zhang, Hong-Mei; Wei, XuHong; Liu, Guosong; Liu, Xian-Guo Oral Application of Magnesium-L-Threonate Attenuates Vincristine-induced Allodynia and Hyperalgesia by Normalization of Tumor Necrosis Factora/Nuclear Factor-kB.Anesthesiology 2017; 126:1151-1168.

12. Zhang Q, Yu J, Wang J, Ding CP, Han SP, Zeng XY, Wang JY. The red nucleus TNF-a paticipates in the Initiation and Maintenance of Neuropathic Pain Through Different Signaling Pathways. Neurochem Res 2015; 40:1360-1371.

13. Blackbeard J, Wallace VC, O'Dea KP, Hasnie F, Segerdahl A, Pheby T, Field MJ, Takata M, Rice AS. The correlation between pain-related behaviour and spinal microgliosis in four distinct models of peripheral neuropathy. Eur J Pain 2012; 16:1357-67.

14. Maftei D, Marconi V, Florenzano F, Giancotti LA, Castelli M, Moretti S, Borsani E, Rodella LF, Balboni G, Luongo L, Maione S, Sacerdote P, Negri L, Lattanzi R. Controlling the activation of the Bv8/prokineticin system reduces neuroinflammation and abolishes thermal and tactile hyperalgesia in neuropathic animals. Br J Pharmacol. 2014; 171:4850-65.

15. Mei XP, Chen L, Wang W, Wu D, Wang LY, Zhang T, Zhang H, Xu LX, Li YQ. Combination of tramadol with minocycline exerted synergistic effects on a rat model of nerve injury-induced neuropathic pain. Neurosignals 2013; 21:184-96.

16. Mei XP, Sakuma Y, Xie C, Wu D, Ho I, Kotani J, Xu LX. Depressing interleukin-1 $\beta$ contributed to the synergistic effects of tramadol and minocycline on spinal nerve ligation-induced neuropathic pain. Neurosignals 2014; 22:30-42.

17. Nieto FR, Clark AK, Grist J, Chapman V, Malcangio M. Calcitonin gene-related peptide-expressing sensory neurons and spinal microglial reactivity contribute to pain states in collagen-induced arthritis. Arthritis Rheumatol 2015; 67:1668-77. 
18. Nieto FR, Clark AK, Grist J, Hathway GJ, Chapman V, Malcangio M. Neuron-immune mechanisms contribute to pain in early stages of arthritis. J Neuroinflammation 2016; 13:96.

19. Sun YE, Peng L, Sun X, Bo J, Yang D, Zheng Y, Liu C, Zhu B, Ma Z, Gu X. Intrathecal injection of spironolactone attenuates radicular pain by inhibition of spinal microglia activation in a rat model. PLoS One 2012;7: e39897.

20. Xu ZZ, Berta T, Ji RR. Resolvin E1 inhibits neuropathic pain and spinal cord microglial activation following peripheral nerve injury. J Neuroimmune Pharmacol. 2013; 8:37-41.

21. Lin CS, Tsaur ML, Chen CC, Wang TY, Lin CF, Lai YL, Hsu TC, Pan YY, Yang CH, Cheng JK. Chronic intrathecal infusion of minocycline prevents the development of spinal-nerve ligation-induced pain in rats. Reg Anesth Pain Med 2007; 32:209-216.

22. Ledeboer A, Gamanos M, Lai W, Martin D, Maier SF, Watkins LR, Quan N. Involvement of spinal cord nuclear factor kappaB activation in rat models of proinflammatory cytokine-mediated pain facilitation. Eur J Neurosci 2005;22: 1977-1986.

23. Ledeboer A, Sloane EM, Milligan ED, Frank MG, Mahony JH, Maier SF, Watkins LR. Minocycline attenuates mechanical allodynia and proinflammatory cytokine expression in rat models of pain facilitation. Pain 2005; 115:71-83.

24. Pabreja K, Dua K, Sharma S, Padi SS, Kulkarni SK. Minocycline attenuates the development of diabetic neuropathic pain: possible anti-inflammatory and anti-oxidant mechanisms. Eur $\mathrm{J}$ Pharmacol 2011;661(1-3):15-21.

25. Lindia JA, McGowan E, Jochnowitz N, Abbadie C. Induction of CX3CL1 expression in astrocytes and CX3CR1 in microglia in the spinal cord of a rat model of neuropathic pain. JPain. 2005; 6:434-438.

26. Old EA, Nadkarni S, Grist J, Gentry C, Bevan S, Kim KW, Mogg AJ, Perretti M, Malcangio M. Monocytes expressing CX3CR1 orchestrate the development of vincristine-induced pain. J Clin Invest $2014 ; 124: 2023-36$.

27. Staniland AA, Clark AK, Wodarski R, Sasso O, Maione F, D’Acquisto F, Malcangio M. Reduced inflammatory and neuropathic pain and decreased spinal microglial response in fractalkine receptor (CX3CR1) knockout mice. J Neurochem 2010; 114:1143-57.

28. Sun JL, Xiao C, Lu B, Zhang J, Yuan XZ, Chen W, Yu LN, Zhang FJ, Chen G, Yan M. CX3CL1/CX3CR1 regulates nerve injury-induced pain hypersensitivity through the ERK5 signaling pathway. J Neurosci Res 2013; 91:545-53.

29. Sun S, Cao H, Han M, Li TT, Pan HL, Zhao ZQ, Zhang YQ. New evidence for the involvement of spinal fractalkine receptor in pain facilitation and spinal glial activation in rat model of monoarthritis. Pain 2007;129:64-75.

30. Verge GM, Milligan ED, Maier SF, Watkins LR, Naeve GS, Foster AC. Fractalkine (CX3CL1) and fractalkine receptor (CX3CR1) distribution in spinal cord and dorsal root ganglia under basal and neuropathic pain conditions. Eur JNeurosci. 2004; 20:1150-1160.

31. Yang JL, Xu B, Li SS, Zhang WS, Xu H, Deng XM, Zhang YQ. Gabapentin reduces CX3CL1 signaling and blocks spinal microglial activation in monoarthritic rats. Mol Brain 2012; 5:18. 
32. Pan YD, Guo QL, Wang E, Ye Z, He ZH, Zou WY, Cheng ZG, Wang YJ. Intrathecal infusion of pyrrolidine dithiocarbamate for the prevention and reversal of neuropathic pain in rats using a sciatic chronic constriction injury model. Reg Anesth Pain Med 2010;35: 231 - 237.

33. Wen C, Xu M, Mo C, Cheng Z, Guo Q, Zhu X JMJD6 exerts function in neuropathic pain by regulating NF-KB following peripheral nerve injury in rats. Int J Mol Med. 2018;42(1):633-42.

34. Hou X, Weng Y, Wang T, Ouyang B, Li Y, Song Z, Pan Y, Zhang Z, Zou W, Huang C, Guo Q. Suppression of HDAC2 in Spinal Cord Alleviates Mechanical Hyperalgesia and Restores KCC2 Expression in a Rat Model of Bone Cancer Pain. Neuroscience. 2018; 377:138-49.

35. Tian G, Luo X, Tang C, Cheng X, Chung SK, Xia Z, Cheung CW, Guo Q. Astrocyte contributes to pain development via MMP2-JNK1/2 signaling in a mouse model of complex regional pain syndrome. Life Sci. 2017; 170: 64-71.

36. Ye Z, Li Q, Guo Q, Xiong Y, Guo D, Yang H, et al. Ketamine induces hippocampal apoptosis through a mechanism associated with the caspase- 1 dependent pyroptosis. Neuropharmacology 2018,128 : 63-75.

37. Bennett GJ, Xie Yikuan. Peripheral mononeuropathy in rat that produces disorders of pain sensation like those seen in man. Pain 1988; 33:87-107.

38. O'Rielly DD, Loomis CW. Spinal nerve ligation-induced activation of nuclear factor kappaB is facilitated by prostaglandins in the affected spinal cord and is a critical step in the development of mechanical allodynia. Neuroscience. 2008; 155:902Y913.

39. Hao S, Mata M, Glorioso JC, Fink DJ. Gene transfer to interfere with TNFalpha signaling in neuropathic pain. Gene Ther. 2007; 14:1010-6.

40. Wu Z, Wang S, Wu I, Mata M, Fink DJ. Activation of TLR-4 to produce tumour necrosis factor-a in neuropathic pain caused by paclitaxel. Eur J Pain. 2015 19:889-98.

41. Inoue K, Koizumi S, Tsuda M. The role of nucleotides in the neuron-glia communication responsible for the brain functions. J Neurochem 2007; 102:1447-1458.

42. Chandrasekar B, Mummidi S, Perla RP, Bysani S, Dulin NO, Liu F, Melby PC. Fractalkine (CX3CL1) stimulated by nuclear factor kappaB (NF-kappaB)-dependent inflammatory signals induces aortic smooth muscle cell proliferation through an autocrine pathway. Biochem J. 2003;373:547-58.

43. Obata N, Mizobuchi S, Itano Y, Matsuoka Y, Kaku R, Tomotsuka N, Morita K, Kanzaki H, Ouchida M, Yokoyama M. Decoy strategy targeting the brain-derived neurotrophic factor exon I to attenuate tactile allodynia in the neuropathic pain model of rats. Biochem Biophys Res Commun 2011;408:139-44.

44. Van der Vorst EP, Vanags LZ, Dunn LL, Prosser HC, Rye KA, Bursill CA. High-density lipoproteins suppress chemokine expression and proliferation in human vascular smooth muscle cells. FASEB J 2013;27:1413-25.

45. Zhou R, Gong AY, Chen D, Miller RE, Eischeid AN, Chen XM. Histone deacetylases and NF-kB signaling coordinate expression of CX3CL1 in epithelial cells in response to microbial challenge by suppressing miR-424 and miR-503. PLoS One. 2013;8:e65153. 
46. Hartung JE, Eskew O, Wong T, Tchivileva IE, Oladosu FA, O'Buckley SC, Nackley AG. Nuclear factorkappa $\mathrm{B}$ regulates pain and COMT expression in a rodent model of inflammation. Brain Behav Immun 2015; 50:196-202.

47. Meffert MK, Baltimore D. Physiological functions for brain NF-kappaB. Trends Neurosci 2005; 28:3743.

48. Liddell JR, Lehtonen S, Duncan C, Keksa-Goldsteine V, Levonen AL, Goldsteins G, Malm T, White AR, Koistinaho J, Kanninen KM. Pyrrolidine dithiocarbamate activates the Nrf2 pathway in astrocytes. J Neuroinflammation 2016; 26; 13:49.

49. Gan AM, Butoi ED, Manea A, Simion V, Stan D, Parvulescu MM, Calin M, Manduteanu I, Simionescu M. Inflammatory effects of resistin on human smooth muscle cells: up-regulation of fractalkine and its receptor, CX3CR1 expression by TLR4 and Gi-protein pathways. Cell Tissue Res 2013;351:161-74.

50. Shin MS, You S, Kang Y, Lee N, Yoo SA, Park K, Kang KS, Kim SH, Mohanty S, Shaw AC, Montgomery RR, Hwang D, Kang I. DNA Methylation Regulates the Differential Expression of CX3CR1 on Human IL-7Ralow and IL-7Rahigh Effector Memory CD8+ T Cells with Distinct Migratory Capacities to the Fractalkine. J Immunol 2015; 195:2861-9.

51. Xiao LJ, Chen YY, Lin P, Zou HF, Lin F, Zhao LN, Li D, Guo L, Tang JB, Zheng XL, Yu XG. Hypoxia increases $\mathrm{CX} 3 \mathrm{CR} 1$ expression via $\mathrm{HIF}-1$ and $\mathrm{NFKB}$ in androgen-independent prostate cancer cells. Int J Oncol 2012;41:1827-1836.

52. Sun JL, Xiao C, Lu B, Zhang J, Yuan XZ, Chen W, Yu LN, Zhang FJ, Chen G, Yan M. CX3CL1/CX3CR1 regulates nerve injury-induced pain hypersensitivity through the ERK5 signaling pathway. J Neurosci Res 2013; 91:545-53.

53. Beg AA, Sha WC, Bronson RT, Ghosh S, Baltimore D. Embryonic lethality and liver degeneration in mice lacking the RelA component of NF-kappa B. Nature 1995; 376:167-70.

54. Lianxu C, Hongti J, Changlong Y. NF-kappaBp65-specific siRNA inhibits expression of genes of COX2, NOS -2 and MMP-9 in rat IL-1beta-induced and TNF-alpha-induced chondrocytes. Osteoarthritis Cartilage 2006; 14:367-76.

\section{Figures}


A
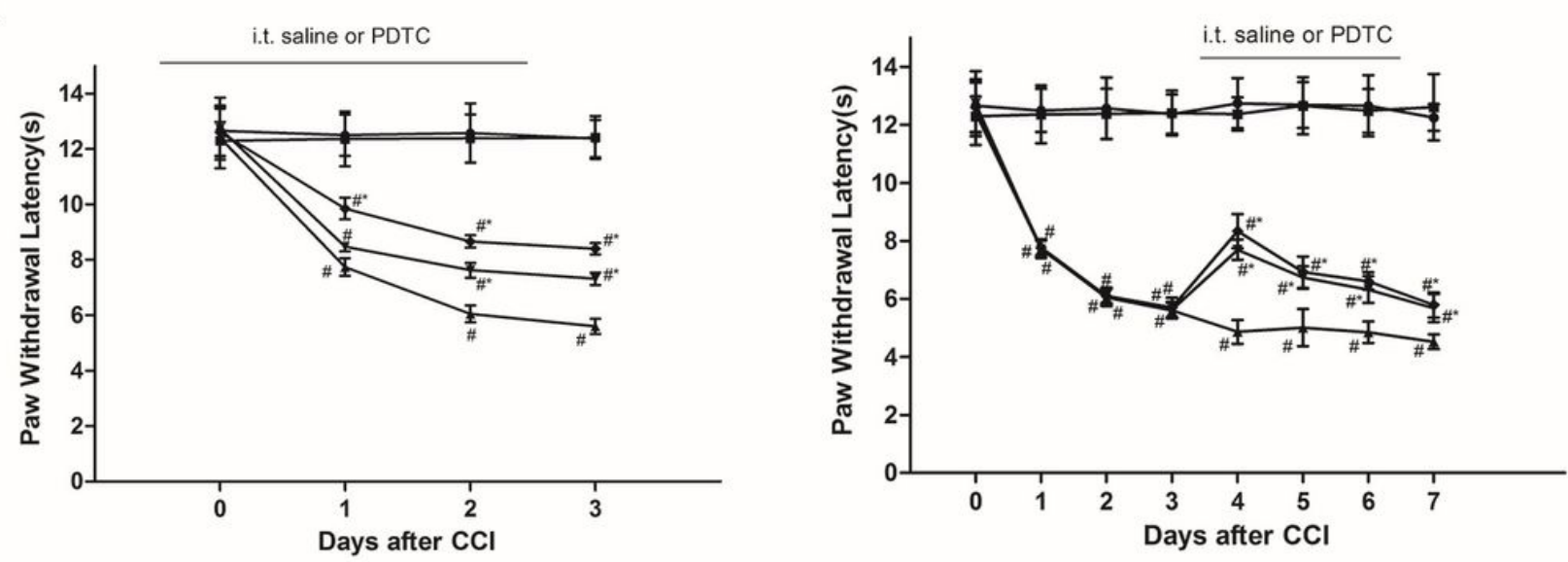

B


\section{Figure 1}

The effects of repeated intrathecal administration of saline or PDTC (100 or 1000 pmol/d, i.t. 4 days) on pain behaviors of ipsilateral hind paw in CCI rats. PWT to electrovonfrey filaments and PWL to radiant heat source of CCl-rats decreased over time. PDTC increased PWT (B) and PWL (A) in a dose-dependent manner in $\mathrm{CCl}$ rats. Results are expressed as mean $\pm \mathrm{SEM}(\mathrm{n}=8)$. Bar above the $\mathrm{x}$-axis represents intrathecal treatment with saline or PDTC. \#, $P<0.05$ vs. saline treated sham rats. *, $P<0.05$ vs. saline treated $\mathrm{CCl}$ rats. 


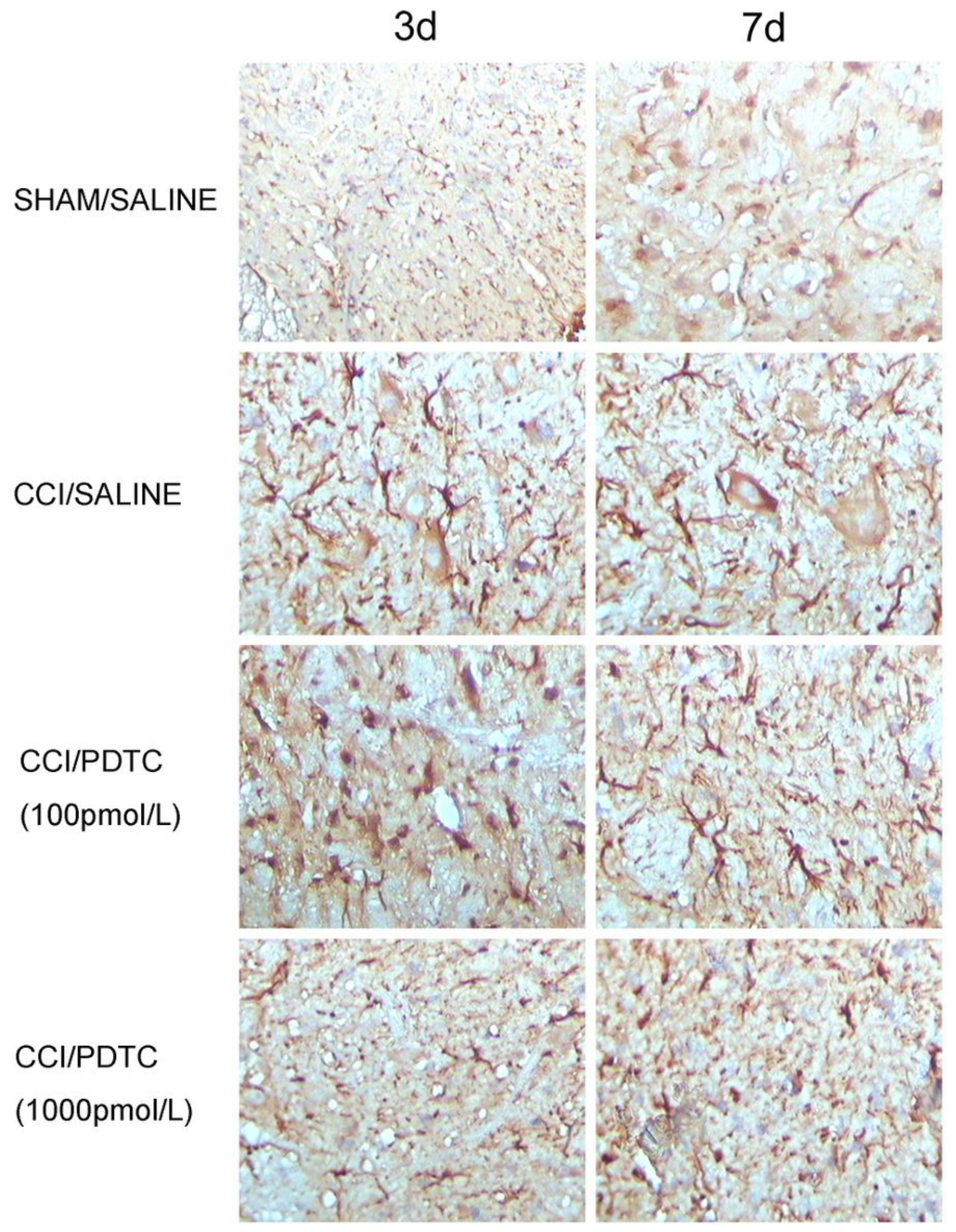

\section{Figure 2}

The effects of repeated intrathecal administration of PDTC (100 or $1000 \mathrm{pmol} /$ d, i.t. 4 days) on spinal microgliosis in rats. Representative photomicrographs of OX-42 immunoreactivity (IR) of ipsilateral L4/5 spinal dorsal cord shows prominent microglial activation in $\mathrm{CCl}$ rats, and CCl-induced microglial activation was remarkably suppressed by PDTC. 




$\square$ SHAM/SALINE
CCI/SALINE
曰 CCI/PDTC(100pmo//I)
血 CCI/PDTC(1000pmo//l)

\section{Figure 3}

The effects of repeated intrathecal administration of PDTC (100 or $1000 \mathrm{pmol} / \mathrm{d}$, i.t. 4 days) on the number of ipsilateral spinal OX-42 IR cells in CCI rats. The number of ipsilateral spinal OX-42 IR cells decreased with PDTC treatment on days 3 and 7 after CCl. Results are expressed as mean \pm SEM $(n=4)$. \#, $\mathrm{P}<0.05$ vs. saline treated sham rats, ${ }^{*}, \mathrm{P}<0.05$ vs. saline treated $\mathrm{CCl}$ rats. 




\section{Figure 4}

The effects of repeated intrathecal administration of PDTC (100 or $1000 \mathrm{pmol} / \mathrm{d}$, i.t. 4 days) on spinal TNF-a protein expression in CCl rats. Representative photomicrographs of TNF-a immunoreactivity of ipsilateral L4/5 spinal dorsal cord of rats show higher TNF-a expression in saline treated CCI rats, and PDTC remarkably suppressed TNF-a expression in CCl rats. 


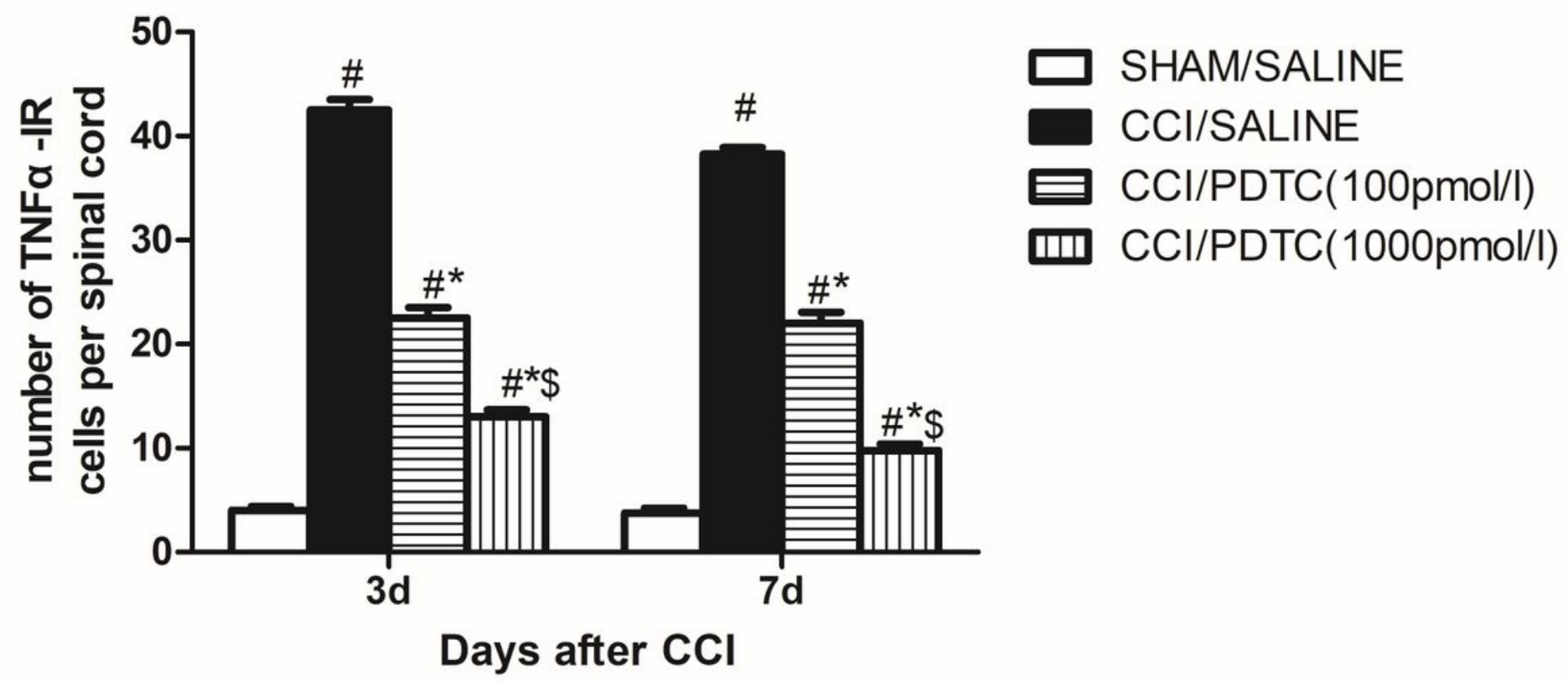

Figure 5

The effects of repeated intrathecal administration of PDTC (100 or $1000 \mathrm{pmol} / \mathrm{d}$, i.t. 4 days) on the number of ipsilateral spinal TNF-a IR cells in CCI rats. The number of ipsilateral spinal TNF-a IR cells remarkably decreased with PDTC treatment on days 3 and 7 after $\mathrm{CCl}$. Results are expressed as mean \pm SEM $(n=4) . \#, P<0.05$ vs. saline treated sham rats, ${ }^{*}, P<0.05$ vs. saline treated $C C l$ rats, $\$, P<0.05$ vs. PDTC-100 pmol/d treated $\mathrm{CCl}$ rats. 


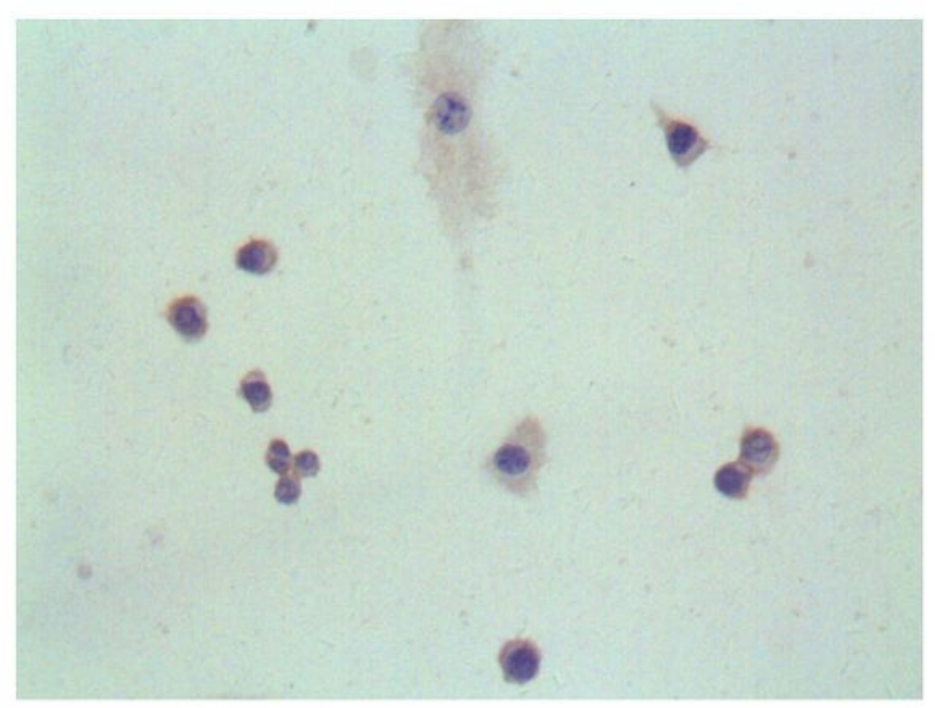

control

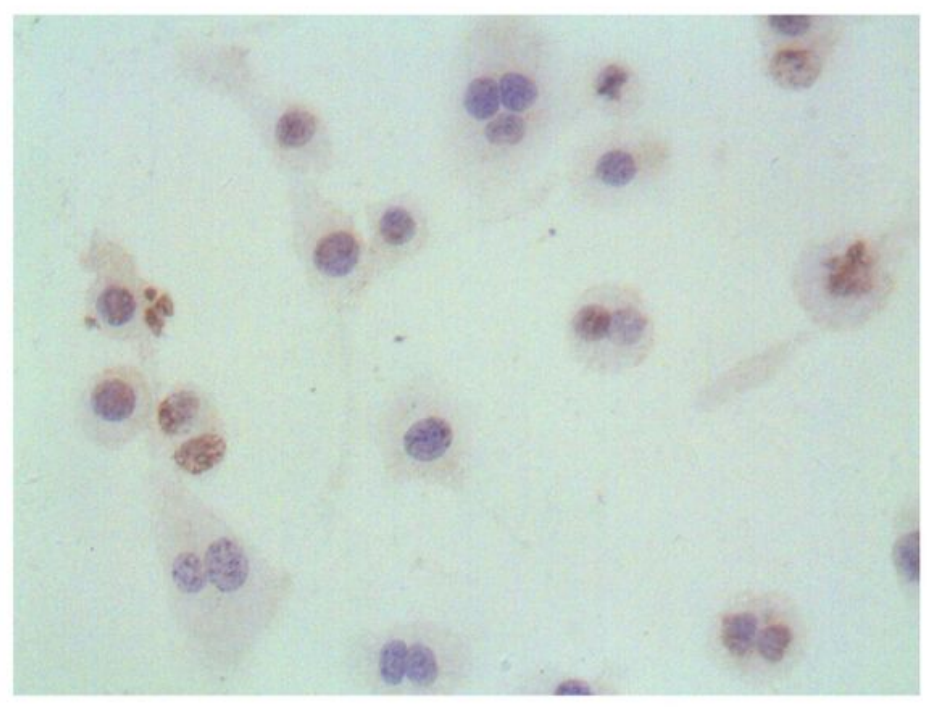

PDTC+TNFa

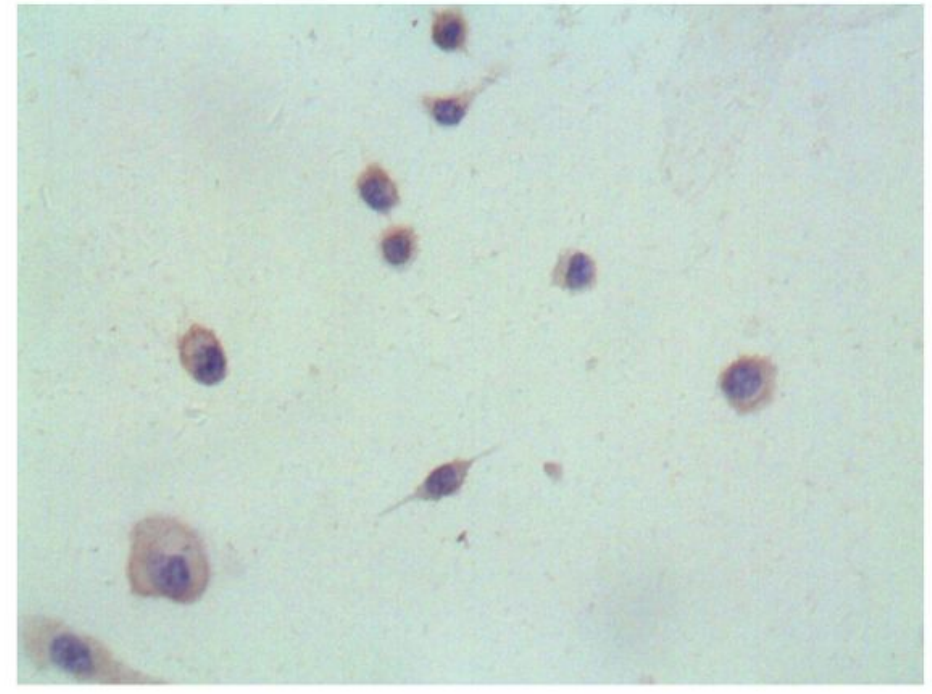

PDTC

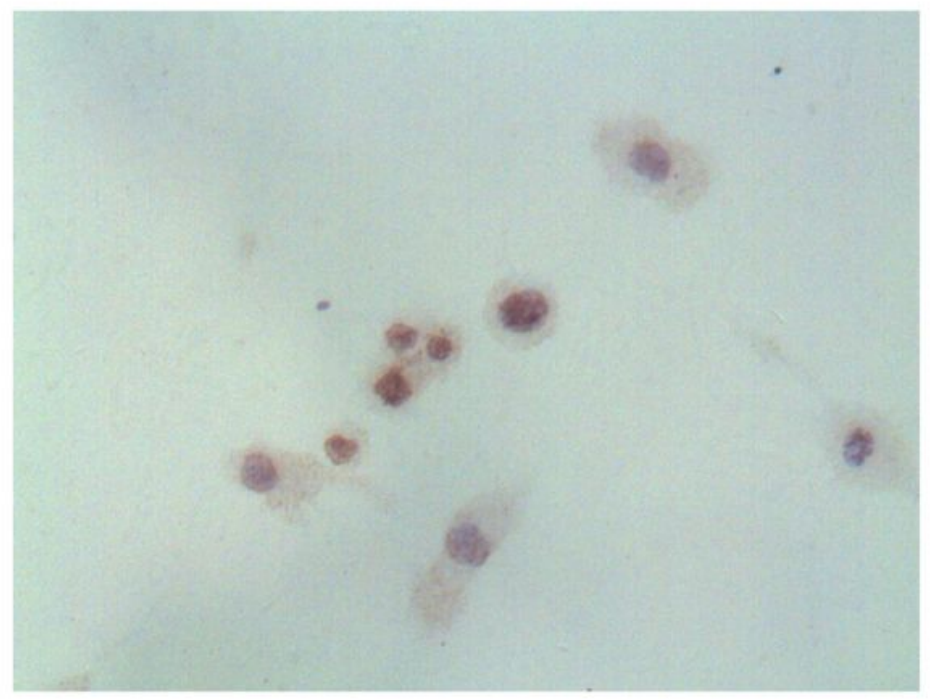

TNFa

Figure 6

Effect of PDTC on p-p65 protein expression in TNFa-induced BV-2 microglial cells. Representative photomicrographs of p-p65 immunoreactivity in BV-2 microglia show increased p-p65 expression in TNFa treated cells. PDTC-pre-treated group had lower p-p65 protein expression than TNFa treated groups did. 


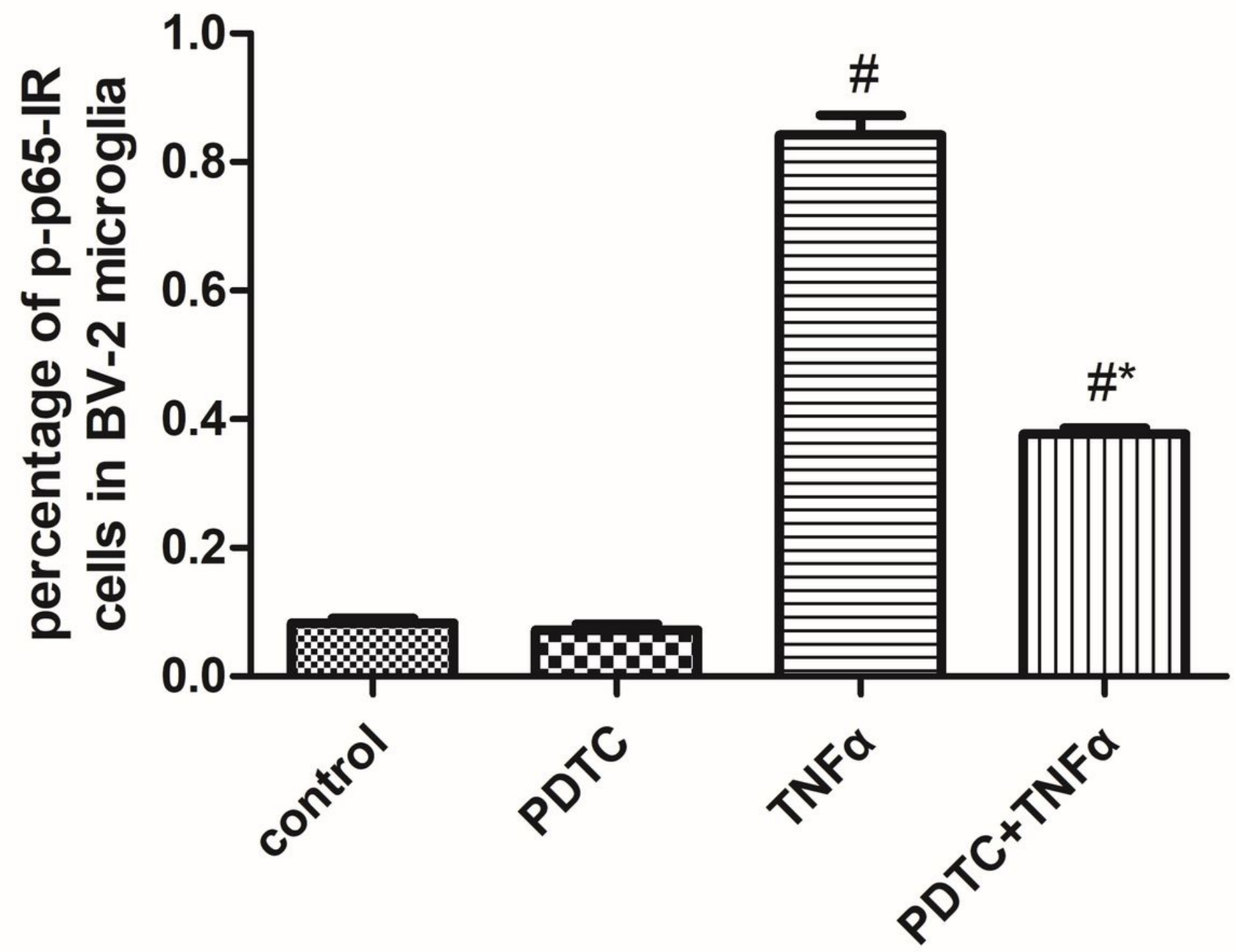

Figure 7

Effect of PDTC on p-p65 IR cells in TNFa-induced BV-2 microglia. Statistical analysis of percentage of pp65 IR cells is shown between different groups. Results are expressed as mean \pm SEM $(n=4)$. The percentage of p-p65 IR cells in BV-2 microglia decreased substantially in PDTC -treatment cells. \#, P <0.05 vs. control cells, *, $\mathrm{P}<0.05$ vs. TNFa treated cells. 
A CON PDTC TNF $\alpha$ PDTC+TNF $\alpha$

$30 \mathrm{~min}$

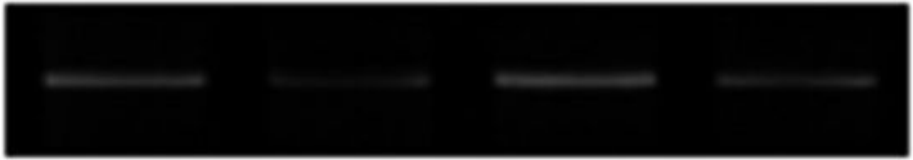

$1 \mathrm{~h}$

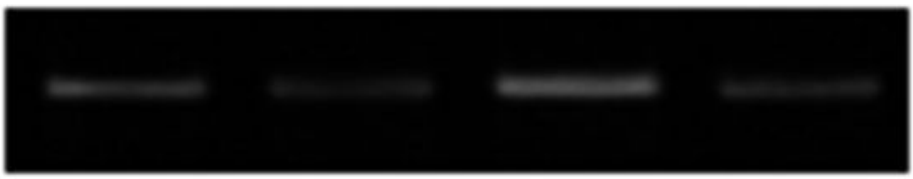

$2 \mathrm{~h}$



$4 \mathrm{~h}$

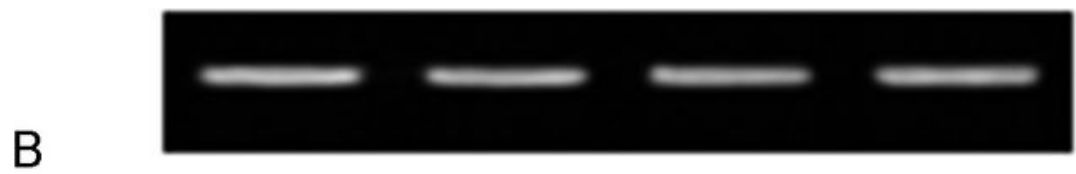

GAPDH

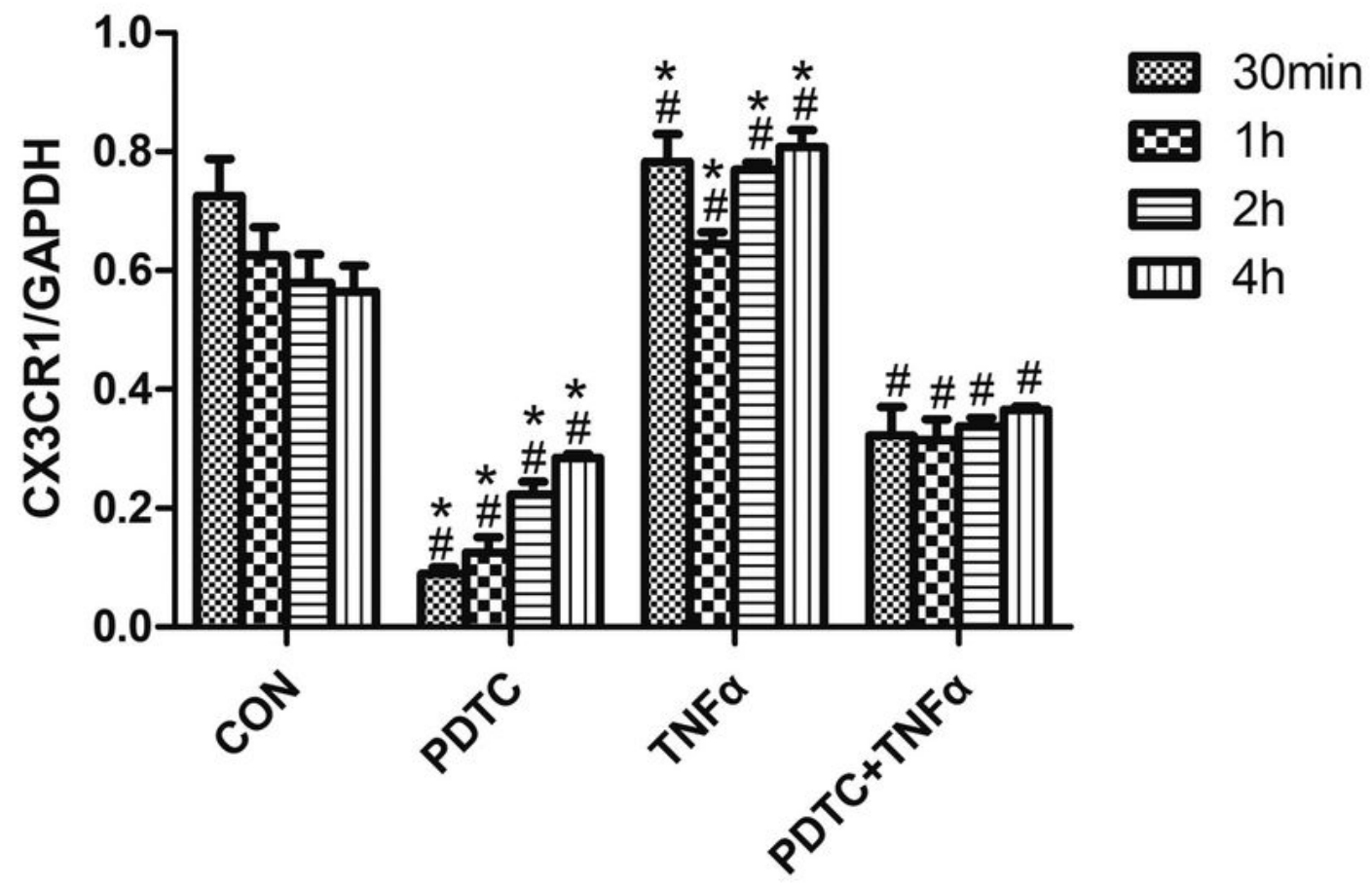

Figure 8

Effect of PDTC on the expression of CX3CR1 mRNA in TNFa-induced BV-2 microglial cells. PDTCtreatment group had lower CX3CR1 mRNA expression than other groups did. A. Bands of RT-PCR of CX3CR1 mRNA expression. B. Statistical analysis of relative density of RT-PCR bands is shown between different groups. Results are expressed as mean \pm SEM $(n=4)$. \#, $P<0.05$ vs. control cells, ${ }^{*}, P<0.05$ vs. PDTC and TNFa treated cells. 
A

\section{CON POTC TNFa POTC + TNFa}

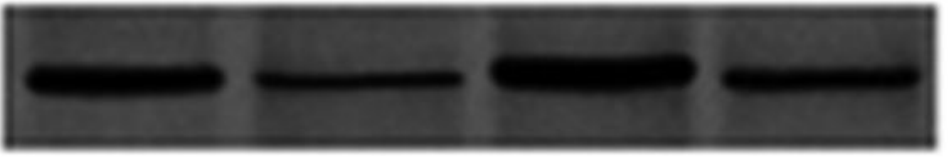

$2 \mathrm{~h}$

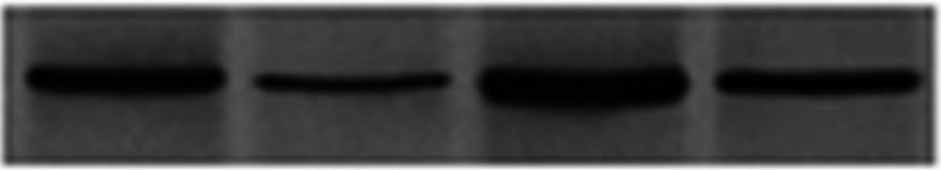

$4 \mathrm{~h}$

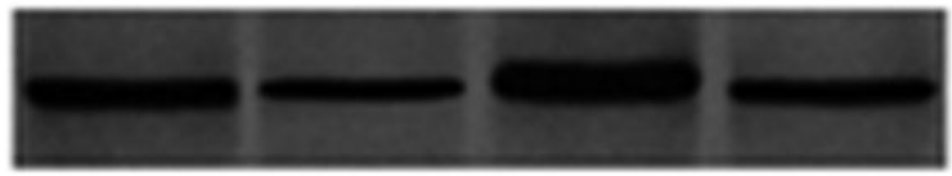

$6 \mathrm{~h}$

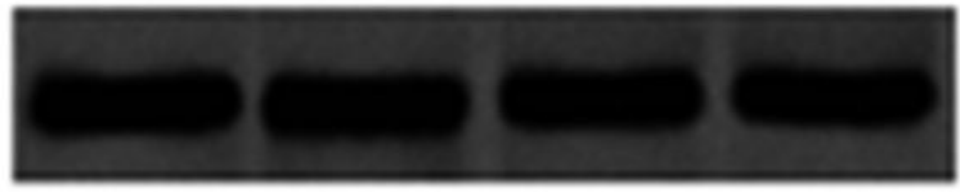

\section{GAPOH}

B



Figure 9

Effect of PDTC on CX3CR1 protein expression in TNFa-induced microglial cells. PDTC-pre-treatment group had lower CX3CR1 protein expression than other groups did. A. Bands of western blotting of CX3CR1 protein expression. B. Statistical analysis of relative density of western blotting bands is shown between different groups. Results are expressed as mean $\pm \operatorname{SEM}(n=4)$. \#, $P<0.05$ vs. control cells, *, $\mathrm{P}<0.05$ vs. PDTC and TNFa treated cells. 


\section{Supplementary Files}

This is a list of supplementary files associated with this preprint. Click to download.

- NC3RsARRIVEGuidelinesChecklistfillable.pdf 